\title{
UNDP/UNFPA 집행이사회 연례회의 결과
}

유엔개발계획(UNDP)/유엔인구기금(UNFPA) 집행이사회 연례회의가 2010.6.21 7.1 스위스 제네바에서 개최되었음. 연례회의에서는 UNDP와 UNFPA의 활동 성과 및 효과성 제고 노력, UN 기관간 일관성 제 고 노력에 관한 보고가 있었으며, UNDP와 UNFPA의 연례보고서, 재정 공약, 평가 연례보고, 감사 보 고 등이 채택됨. 동 회의에는 외교부 및 $\mathrm{KOICA}$ 로 구성된 대표단이 참석하였으며, 회의주요 내용을 아 래와 같이 보고하였음.

\section{I. 핵심요지}

\section{UNDP 부분}

1) UNDP 총재 발언 요지

Helen Clark UNDP 총재는 UNDP의 개혁의지를 천명하면서 구체적 사업행동계획(Business Action Plan) 목표를 제시하고, 2008 2013 전략계획(Strategic Plan) 실행에 따른 UNDP의 성과를 소개함.

UNDP 관리그룹(Management Group)은 2010.2 회의를 거쳐 UNDP의 전략계획과 비전을 달성하 기 위하여 보다 효과적이고 효율적인 기구로 변모하기 위하여 7 개의 핵심 요소로 구성된 UNDP 사업행동계획(Business Action Plan)을 제시. 7대 핵심 요소로는 i) 세계적 수준의 지식 기반 기 관으로 변모, ii)결과 중심 관리, iii) 전략적 커뮤니케이션, iv) 전략적 파트너쉽 강화, v) 직원들 에 대한 성과 관리 및 역량 강화, vi) 업무의 효과성 및 효율성 제고를 위한 제도 개선, vii) UN 의 개발활동 조정기능 강화임.

2008 2013년 전략계획에 따른 성과 보고서로 “빈곤퇴치 및 MDG 달성” 분야의 결과(outcome)분 석 및 2009년 연례보고서의 내용을 소개하고, “Delivery as One”을 비롯한 UNDP 주도의 UN 개 혁 노력을 강조 


\section{2) 주요 채택 결의안 내용}

이사국들은 $\mathrm{UNDP}$ 연례보고서에 대하여 사업행동계획과 같은 내부역량강화 노력을 환영하며, 향 후 빈곤퇴치와 $\mathrm{MDG}$ 달성이라는 $\mathrm{UNDP}$ 의 최우선 목표를 비롯하여, 역량개발(capacity building) 과 양성평등 등 범분야(cross-cutting) 이슈까지 $\mathrm{UNDP}$ 의 노력 확대를 요청. 아울러 경제·금융위 기·분쟁과 재난의 영향에 취약하고 $\mathrm{MDG}$ 달성 정도가 낮은 개도국에 대한 프로그램 설계 및 적절 한 자원 배분을 촉구. $\mathrm{UNDP}$ 의 전략계획 목표달성에 필수적인 유능한 인적자원 보유를 강조함.

재정 공약에 대하여 이사국들은 안정적이고 예측가능한 정규재원(core contribution) 확보의 중요 성을 강조하고, 비정규재원이 정규재원을 계속 초과하고 있는 데 대한 우려를 표시. 이에 따라 정 규재원의 보충적 수단으로 비정규재원의 역할 및 그 증가를 인정하면서도, 비정규재원은 개도국 개발에 대한 일관성 및 주인의식을 지지하는 방향으로 사용된다고 강조함.

평가연례보고 및 평가정책에 대하여 이사국들은 평가 사무소의 독립성 제도화, 평가의 독립성과 분권화를 위한 국가수준의 접근 및 참여 강화, 비용 및 예산이 반영된 평가 계획 도입 등을 수정 하여 줄 것을 요청함.

\section{UNFPA 부분}

\section{1) UNFPA 총재 발언 요지}

Thoraya Ahmed Obaid UNFPA 총재는 2009년 연례보고서의 내용을 개발활동 및 조직관리 성과 의 두 측면으로 나누어 자세히 소개하고, 2015년 MDG 달성을 위한 향후 계획을 소개

개발활동 부문에서는 3 대 중점 분야에 대한 사업 성과 및 남남협력의 촉진, 개도국의 역량 강화 지원 확대, 민간 기업과의 협력(PPP) 확대, 사업현장에서 유관 UN 기구들과의 공조 강화 현황을 설명. 조직관리 부문에서는 $\mathrm{UNFPA}$ 의 평가역량 강화, 외구 기술고문 활용 등의 성과 함께 새로운 도전과제로서 UNFPA 프로그램 추진을 위한 개도국 시스템의 역량 강화를 언급함.

$\mathrm{UNFPA}$ 는 $\mathrm{MDG}$ 목표 연도를 5년 앞둔 시점에서 G8/G20, MDGs 정상회의 등을 계기로 MDG5, ICPD Program of Action 달성을 가속화하기 위한 국제적 모멘텀을 강화해 나갈 예정임을 설명하 고, 6월 G8 정상회의에서 모자보건을 개발의제로 채택한 캐나다에 사의를 표명 


\section{2) UNFPA 재정 보고 및 평가 정책}

UNFPA는 재정 보고에서 2009년 재원 조달 성과 및 2010년 재원 조달 현황과 예측치를 설명. 2009년 기준 정규 기여금은 467.9백만불, 비정규 기여금은 270.1백만불임. 2010년 6월 15일 현재 2010 년 정규 기여금 예상치는 457.6백만불, 비지정 기여금 수령액은 133 백만불임. UNFPA는 사 업의 안정적 추진 및 효과적 재원 배분을 위하여 비지정 기여금, Thematic Fund 및 다년간 예산 공약에 대한 공여국들의 적극적 참여를 요청

평가 정책 이행 보고에서 UNFPA는 2008 2009년단 평가 가이드라인의 개선, 지역 사무소에 평 가 전담자 지명, 직원 교육, 평가 활동의 인사 고과 반영 등 평가 역량 강화를 위한 다양한 노력 을 소개. 회의 참가국들은 결과 중심 관리를 위한 수혜자 평가의 강화, UN기구를 포함하여 다양 한 개발 행위자간의 일관성 있는 평가, 국가 프로그램에 평가 결과 반영 등의 분야에 대한 개선을 요청하였으며, 이에 대하여 총재는 평가 역량 강화를 위한 재원 확대 및 전문 인력 확보에 대한 협조를 이사국에 요청함. 